\title{
Impact of Oil Price Changes on the Economic Performance of Major Oil Exporting \& Oil Importing Countries
}

\author{
SAHADAT HOSSAIN, PROF. DR. ANNUAR BIN MD. NASSIR \\ Universiti Putra Malaysia, Malaysia
}

\begin{abstract}
Oil is an important energy source, embodies the largest commodity market in the world which is considered as an important macroeconomic factor that can cause direct impact on different economic variable. The main objective of this paper is to analyze the effects on core economic variables of the major oil exporting and oil importing countries as a result of oil price changes. The study used Time Series data covering the time period from 1960 to 2015 for five largest oil exporting and five largest oil importing countries by applying Vector autoregressive model. Reviewing the literature, economics variables that have been considered in the study are: Oil Prices (OP), Inflation taken as consumer price index on the basis of annual percentage increase (CPI), Inflation taken as annual percentage increase GDP, Real interest rate, Official exchange rate, and Net domestic credit. Applying Johansen Co-integration techniques, relationship among different variables has been analyzed in long run and short run. In order to find the short run relationship, Error Correction Model technique is used. It has been observed from the analysis that the economic variables respond differently in term of oil price changes in oil exporting countries as compared to oil importing countries. Both oil importing and oil exporting countries show a long run and short run relationship among the core economic variables. Hence, general conclusion from this study can be deduced that there exists a strong relation among economic variables and oil price fluctuations; however, the intensity of relationship varies amid the countries.
\end{abstract}

Keywords: CPI; exchange rate; GDP; interest rate; oil price effects. 